\title{
Enhancing science and technology cooperation between the EU and Eastern Europe as well as Central Asia: a critical reflection on the White Paper from a S\&T policy perspective
}

Klaus Schuch ${ }^{1 *}$, George Bonas ${ }^{2}$ and Jörn Sonnenburg ${ }^{3}$

\begin{abstract}
This article reflects the main findings of the 'White Paper on opportunities and challenges in view of enhancing the EU cooperation with Eastern Europe, Central Asia and South Caucasus in Science, Research and Innovation', which was released in April 2012, from a science and technology (S\&T) internationalisation policy perspective. In the 'Internationalisation of R\&D from an S\&T policy perspective' section of this article, the ongoing discourse on internationalisation of research and development (R\&D) is discussed from an S\&T policy perspective. In the 'S\&T cooperation between the EU and Eastern Europe as well as Central Asia since the early 1990s' section, the development of S\&T cooperation between the EU and EECA is described as a historical snapshot since the early 1990s. In the 'Recent S\&T internationalisation efforts of Eastern European and Central Asian countries' section, special emphasis is given to the current EECA countries' dispositions towards R\&D internationalisation. For a structured overview, the EECA region is disaggregated in three subregions, namely, (a) Russian Federation, (b) Eastern European countries (without Russia) and (c) Central Asian countries. To better position the R\&D internationalisation policies of the region under scrutiny within the overall state-of-the-art of S\&T, the 'Current state of S\&T in the Eastern European and Central Asian countries' section compares main S\&T indicators of the EECA countries. The 'The White Paper recommendations in the light of international S\&T cooperation policy objectives' section finally condenses the major recommendations elaborated during the White Paper consultation process and puts them into the context of international S\&T cooperation policy. The question is raised on what international cooperation can contribute to improving S\&T in the EECA region and which approaches are deemed most adequate to support this. The analysis shows that most recommendations suggested in the White Paper directly target the S\&T policy (delivery) system, which is put into an explicit actor's role. Science diplomacy is the identified predominant driver for deepening international R\&D cooperation with the EECA region. The main instruments used are international dialogue, exchange and learning platforms, which are supported by the European Commission according to the EU's subsidiarity principle. Other S\&T internationalisation policy objectives play a role too, especially if a more regionally differentiated perspective is taken into account.
\end{abstract}

Keywords: R\&D internationalisation, Science diplomacy, Eastern Europe, Central Asia, ERA international dimension

\footnotetext{
* Correspondence: schuch@zsi.at

'Centre for Social Innovation, Linke Weinzeile 246, Wien 1150, Austria

Full list of author information is available at the end of the article
} 


\section{Background}

\section{Internationalisation of R\&D from an S\&T policy perspective}

Internationalisation of research and development $(R \& D)$ is a phenomenon which received attention only recently and for which insufficient data and data comparability are characteristic elements (Edler and Flanagan 2009; OECD 2005; Schuch 2011). The academic focus on R\&D internationalisation is predominantly actor-focussed, with a strong emphasis on private, industry-driven R\&D (Cantwell 1995; Dalton and Serapio 1999; Narula and Zanfei 2004; OECD 2008; Verbeek and Shapira 2009) and with secondary emphasis on public R\&D organisations. The fundamental typology of Archibugi and Michie (1995), who differentiate between exploitation, cooperation and generation within international $R \& D$ cooperation, is an influential example for this actor-centred approach, which puts industry-driven $R \& D$, especially of multinational enterprises, in the centre of investigations. The role of S\&T policy for R\&D internationalisation is regarded primarily as an accompanying 'enabling' or - at least - 'preventing' framework. The enabling function comprises the development of stimulating incentives or support programmes such as cross-border $R \& D$ programmes and/or the openness of national programmes and projects (Edler et al. 2002), while the preventing function primarily concerns the protection of intellectual property at an international scale. Above all, however, the main task of public S\&T policy towards internationalisation of $R \& D$ is to keep its own house clean, i.e. to be an attractive place for conducting R\&D and, thus, for attracting $R \& D$ inflows from abroad too (Verbeek and Shapira 2009).

In 2008, a Comité de la Recherche Scientifique et Technique (CREST) ${ }^{\mathrm{a}}$ working group made a comprehensive attempt to analyse public S\&T policies of 21 European countries $^{\mathrm{b}}$ towards $\mathrm{R} \& \mathrm{D}$ internationalisation by placing R\&D and innovation policy in an actor's role (Sonnenburg et al. 2008). This study clearly revealed that in most countries, which participated in this working group, national S\&T policies actively started to deal with internationalisation of R\&D, not just to let it happen, but to support it and even to direct it. Examples for this proactive understanding are incentives to attract inward corporate and institutional $R \& D$, to participate in cross-border research programmes, to invest in joint $R \& D$ labs abroad and to support the mobility of researchers or the coordination of R\&D internationalisation policies among European Union (EU) Member States and countries associated to the EU RTD Framework Programme towards third countries. Basically, two different sets of R\&D internationalisation objectives could be distinguished: an intrinsic dimension, which puts goals into the centre of public S\&T policy that directly aim to substantiate $S \& T$ (e.g. trough enabling R\&D cooperation among the best researchers globally or to find joint solutions for large-scale R\&D infrastructures which cannot be financed by a country on its own); and an extrinsic dimension, which rather focuses on goals that are meant to support other policies (e.g. facilitation of access to foreign markets through standard settings or research for development to assist technical development cooperation). The CREST study, however, also revealed that interventionist approaches of (primarily national) S\&T policy towards $R \& D$ internationalisation addressed first-of-all public R\&D organisations and agencies. In addition, some measures of more generic nature were triggered by public S\&T policy while an explicit focus on the private business-enterprise sector was rather limited but progressively taken up in the academic discourse (Edler 2008; Rama 2008). Little is yet known about the drivers of public R\&D organisations to participate in international $R \& D$ cooperation, but Edler (2007) identified in German public research organisations the following main motivations to internationalise, which might also be of relevance in other European countries: firstly, access to and utilisation of excellent and complementary knowledge abroad and, secondly, to secure funding (mainly via EU sources), followed by building up of reputation and visibility of the public R\&D organisation. In contrast to the industrial sector (Sachwald 2008), cost advantages did hardly account.

These motives overlap with the main drivers of R\&D internationalisation from a public policy perspective, which were identified by the CREST working group and which were confirmed by Boekholt et al. (2009), who included in their comparative study also policy examples from non-EU countries. Basically, the CREST working group identified the following objectives that drive $R \& D$ internationalisation from an S\&T policy perspective:

- Quality acceleration and excellence

- Market and competition

- Resource acquisition

- Cost optimisation

- Global or regional development

- Science diplomacy

Different rationales are guiding these objectives: the rationale behind the quality acceleration and excellence objective is primarily an intrinsic one that assumes that international $R \& D$ cooperation improves the domestic science base, leading to faster and improved scientific progress as well as enhanced scientific productivity, and is also supportive for the professional advancement of the involved researchers (e.g. trough joint publications in acknowledged international journals). Behind this assumption stands the idea that only the 'best' (institutions and/or researchers) succeed also in international competitive procedures. ${ }^{\mathrm{c}}$ The rationale behind the extrinsic market and competition objective is to support the 
market entry of domestically produced technologies/ innovations abroad as well as to support the access to and a quick uptake of technologies produced abroad within the domestic economy. Here, absorption capacities and the availability of efficient spill-over mechanisms are of importance. The rationale behind the resource acquisition objective overlaps partly with the two major objectives mentioned before. The access to information, knowledge, technology and expertise as well as to singular equipment/facilities and materials are in the focus. However, resource acquisition is not limited to different codified and tacit dimensions of technology transfer but extends to brain gain, gaining of solvent students (for universities) and increasingly also gaining research funds from abroad or from multilateral or international sources. The cost optimisation objective from a public S\&T policy focus does not primarily mean to use cost arbitrages (e.g. lower wages in a foreign country) as this might be a rational argument of the corporate sector, but rather focuses on cost sharing approaches to create critical mass in a certain science arena, e.g. to establish large-scale research infrastructures, and it also includes the rational of risk sharing. The assumption behind the global or regional development objective is the comprehension that many risks have no frontiers (e.g. infectious diseases or climate change) or cannot be solved without international cooperation and solidarity (e.g. Millennium Development Goals) and, thus, have to be tackled through international R\&D collaboration (e.g. research for development). Also, the science diplomacy objective often refers to global challenges and to development cooperation agendas. Fundamentally, it has two main rationales: firstly, to support through R\&D cooperation other external policy dimensions in terms of science for diplomacy (e.g. non-proliferation of mass destruction weapons through keeping former weapon researchers busy with civilian R\&D projects) and, secondly, to promote its own science base abroad in support of other objectives already mentioned above (e.g. to attract 'brains' or to promote a general quality trademark like 'made in Germany').

Public S\&T policies towards R\&D internationalisation have both a strong 'inward' dimension, which is to reinforce the domestic science base through attraction of foreign resources (e.g. human resources, knowledge or foreign funds), and a strong 'outward' dimension in linking domestic actors to knowledge produced abroad (Edler and Boeckholt 2001). Another channel for absorption is to integrate foreign actors into cooperation programmes (Verbeek and Shapira 2009). The latter aspect of R\&D internationalisation has been taken up by the European Commission in the European Framework Programmes (FPs) for Research, Technological Development and Demonstration (RTD).
The most recent communication of the European Commission (EC) on internationalisation, which gives orientation for FP7, puts the issue of excellence through competition (or better: co-opetition ${ }^{\mathrm{d}}$ ) in the forefront: 'Excellence in research stems from competition between researchers and from getting the best to compete and co-operate with each other. A crucial way to achieve this is [...] to work together across borders' (European Commission 2008, p. 4). This stems from the belief that the EU does not claim to be a self-sufficient entity in the realm of S\&T and innovation, but that both Europe's knowledge resource (e.g. human capital) and its role in the global economy will be increasingly shaped by its ability to source knowledge internationally and to adapt it for its own use. In the EC's green paper on the European Research Area (ERA), in which six key features were outlined to structure the ERA, the last key feature addresses the opening of the ERA to the world with special emphasis on neighbouring countries and a strong commitment in addressing global challenges with Europe's partners (European Commission 2007).

While a development policy approach ('research for development') was the main driver in FP3 for the opening up of the European Framework Programme in dedicated thematic niches (e.g. agro-food related $R \& D$ ), this approach was soon complemented by a more explicit S\&T diplomacy approach towards Eastern Europe and the New Independent States of the Former Soviet Union (NIS) after the breakdown of the communist hegemony and the collapse of the Soviet Union. On one hand, this S\&T diplomacy approach was driven by the geopolitical concern to bring Central European Candidate Countries closer to the EU and it's upcoming research area (and then to integrate them). On the other hand, this approach was driven by a neighbourhoodoriented stabilisation policy with a special focus on nonproliferation of mass destruction weapons in the NIS. In the following chapter, the development of S\&T cooperation relations between the EU and the Eastern European and Central Asian (EECA) countries is summarised in a historical perspective.

\section{Results and discussion}

\section{S\&T cooperation between the EU and Eastern Europe as}

\section{well as Central Asia since the early 1990s}

International science and technology cooperation between the EU, its member states and the post-socialist Eastern European and Central Asian countries began soon after the collapse of the hegemonic communist system in early 1990s. At community level, the European Commission pursued and supported collaborative trans-European $R \& D$ efforts whose main aims were to safeguard and strengthen the S\&T potential in the EECA partner countries by orienting research towards new socioeconomic needs of the transition countries, to prevent proliferation of military-relevant knowledge and to generate and disseminate new scientific 
and technological knowledge by encouraging enterprises and research institutes from the East and West to carry out joint research projects and to organise technology transfer under the European FPs for RTD. In FP4, which lasted from 1994 to 1998, the PECO and COPERNICUS schemes were the EC's main mechanism for stimulating S\&T cooperation between researchers from the EU and researchers from the Central European Candidate Countries as well as from the New Independent States of the Former Soviet Union (NIS). The EC spent 241 million ECU in FP4 under those schemes for more than 500 projects involving 3,286 participants (i.e. research entities from the university sector, industrial sector or non-university research sector) (European Commission 1999). Forty-six percent of the approved projects involved only participants from the Central European Candidate Countries and the EU15 (as well as countries associated to the FP at that time). Twenty-one percent involved only participants from the NIS and the EU15 (plus associated states), and $33 \%$ involved participants from all three major regions. Among all target countries, Russia had the most participants under COPERNICUS (FP4) followed by five Central European Candidate Countries, while Ukraine ranked 7th and Belarus, 10th (Schuch 2005).

In addition to COPERNICUS, scientific co-operation with the NIS was also supported by the International Association for Cooperation with Scientists from the former Soviet Union (INTAS), which was established as an international association under Belgian law in 1993 (INTAS 1995) by the European Commission, the EU member states and countries associated to the EU RTD Framework Programme. Until the turn of the millennium, more than 20,000 individual scientists from the NIS had been involved in approximately 2,000 INTAS projects. From 1993 to 1998, the association's budget totalled $€ 121$ million to which another overall budget of $€ 75$ million (European Commission 2000) has been added from 1998 until the end of 2002. While COPERNICUS was governed by the EC directly, the INTAS members had a strong influence on the governance of INTAS.

To complete the picture, it has to be noted that the EU together with the USA, Japan and the Russian Federation established the International Science and Technology Centre (ISTC) in Moscow in 1992, whose membership enlarged since then. The primary aim of ISTC is to offer opportunities to scientists working in the former Soviet Union's military research programmes to redirect their skills towards civilian research and to prevent the expertise and technologies of weapons of mass destruction from proliferating. In 1993, a similar agreement was signed between the USA, Canada, Sweden and Ukraine to establish the Science and Technology Centre of the Ukraine in Kiev. Subsequently, Sweden was replaced by the European Union.

Using these different co-operation instruments focusing primarily on joint $R \& D$ projects, loose individual contacts among researchers from EU and EECA countries were strengthened and transformed into more sustainable scientific relations. Although the disbursed foreign grants could not counterbalance the dramatic drop in $R \& D$ expenditures in the NIS, they at least had a positive impact on the diffusion of new approaches and methodologies as well as standards and model practices (Le Gohebel et al. 2011).

This first phase of the EU's R\&D cooperation with the EECA region coincided with heavy sociocultural transformation processes, which forced the research systems in Eastern Europe and Central Asia to change, not due to emerging new and proactive stimuli or ideas about efficient national innovation systems, but mainly as a result of the severe socioeconomic transition crisis in which S\&T - despite some lip service - was usually not treated as a priority policy area in the countries concerned (Schuch 2005). Although the decline of the educational and research systems in the region under scrutiny was already apparent during the last years of the old regime, the downturn in economic activity during the first phase of the transformation process and the beginning of restructuring was accompanied by an accelerated winding down of the research capacities. It is worthwhile noting, however, that in times of state-socialism, statistics tended also to overestimate R\&D in comparison with OECD calculations (Godin 2001; Gokhberg et al. 1999).

Evidently, until the turn of the millennium, R\&D cooperation between the EU and the Eastern European and Central Asian countries was predominately driven by science diplomacy rationales (stabilisation of S\&T systems of neighbouring countries; non-proliferation of military know-how; support to foreign policy). Although some centres of excellence were recognised (especially in the fields of space research, materials and nuclear research), only Russia and Ukraine were, from the very beginning, considered as levelplaying field partners, with whom international S\&T cooperation has had a prevailing intrinsic research value in terms of achieving excellence through $R \& D$ cooperation.

The drivers of, and as a consequence, the instruments for international S\&T cooperation between the EU and EECA countries started to gradually change at the beginning of the new millennium. This has been caused by several factors, such as the following:

- The economic recovery of most EECA countries

- A reclaimed self-confidence of Russia

- Consolidated structural changes in the national innovation systems in some EECA countries

- The emergence of new global players within the S\&T arena (e.g. BRICS)

- The 'eastern' enlargement of the EU

- A general opening of FP6 and FP7 towards international partner countries 
- An enhanced deliberation and importance gain of international S\&T cooperation policy in general, leading - among other things - to more differentiated and targeted international S\&T cooperation approaches

INTAS became one of the fist 'victims' of this reorientation. Although the programme proved to be successful (Idenburg et al. 2004), it could not be adapted to a changing policy environment and ceased its operations at the end of the first decade of the new millennium. This was especially disadvantageous for the economically less advanced EECA countries since they hardly had capacities to withstand the higher competition exercised within the sixth and seventh FPs, which generally opened up for participation of international partner countries. Although the interest of Central Asian institutions in participating in FP7 is broad, in fact, only 34 institutes succeeded in different $S \& T$ projects within FP7 (data until May 2011). These participations were supported by the EC with a mere budget of $€ 1.7$ million. With 17 participations, Kazakhstan was the strongest partner from this region. Discussions with policy makers from Central Asia revealed that the European Framework Programme for RTD is rather a distant concept to them, while INTAS is still more present in their heads. A reason for this lack of awareness is also the underdeveloped FP7 National Contact Point (NCP) system in Central Asia. With 14 thematic NCPs and 1 national coordination office, Kazakhstan has the most developed NCP system in the region. A similarly advanced structure can only be found in Uzbekistan (13 NCPs). Overall, however, the existing FP7 national information points in the region are not directly supported financially by their national governments (Sonnenburg et al. 2012).

The participation of research teams from Russia in successful projects supported under the European Framework Programmes for RTD differs significantly from all other EECA countries. Until the beginning of FP7, Russia has had consistently the highest project participation among the group of all 'third countries'. Its leading status as a preferential third partner country within FP7 is only contested by the USA. Under the framework of FP7, Russia, which concluded a first S\&T agreement with the European Commission already in 1999, implements several 'coordinated calls' with the EU, which are jointly defined and funded. Since 2001, S\&T agreements between the EU and Russia are also in place for EURATOM covering fission as well as fusion-oriented research.

The participation of the other Eastern European countries in FP7 lies - generally speaking - in between the one of Russia and that of the Central Asian countries. Up until the end of 2010, the majority of countries had a quite limited number of successful proposals, and the EC funding for the Eastern European countries' participants (except
Russia) under FP7 ranges between $€ 1$ to $€ 3$ million per country. The only exception is Ukraine which had 103 successful proposals with an EC contribution reaching approximately $€ 12$ million. All Eastern European countries have a developed NCP structure in place to support domestic researchers in their aspirations to succeed in the competitive FP7 calls for proposals. In some countries, the NCPs are financially supported by the national authorities (e.g. Moldova, Ukraine). In some other countries, NCPs are not directly funded (Armenia, Belarus, Georgia).

\section{Recent S\&T internationalisation efforts of Eastern European and Central Asian countries}

International S\&T cooperation with the EECA countries, however, does not only occur under the European Framework Programmes for RTD. A variety of different policies and instrument are in place to substantiate international $R \& D$ cooperation. In order to provide a structured overview, we disaggregate the EECA region in three distinct subregions:

1. Russian Federation

2. Eastern European countries (without Russia) and

3. Central Asian countries

Information provided in this section, if not indicated differently, is taken primarily from the White Paper (Sonnenburg et al. 2012) and the analytical deliverables produced under the INCO-NET - EECA project, which can be accessed through the internet. ${ }^{\mathrm{e}}$

\section{International S\&T cooperation in the Russian Federation}

Enhancing internationalisation of the R\&D sector has been identified by Russian policy makers as one important aspect for improving the quality and results of the Russian R\&D system. Internationalisation in Russia, however, starts from a low level. Still, many R\&D organisations are isolated from each other and from the outside world. Data on co-publication show that the USA and some EU countries (Germany, France, UK and Italy) are the top collaborating partners. Co-operation with China and South Korea is quickly increasing. A few Russian R\&D programmes are also open for participation of EU researchers. ${ }^{\mathrm{f}}$ Main access obstacles are a lack of information about Russian research programmes, linguistic barriers and financial and legal issues.

Russia has bilateral agreements and programmes in place with many states all over the globe. Since 1991, the USA have always been an important partner and among the first and largest investors in the Russian science and technology. The EU is another important partner for Russia's R\&D internationalisation efforts. Russia has concluded bilateral S\&T agreements with a broad range of EU member states and countries associated to 
the FP. At the level of research organisations, especially the Russian Academy of Sciences has a well-stocked network of cooperation agreements. Agreements have also been established at the level of research funds.

Findings of a survey conducted under the ERA.NET RUS project proved that bilateral international cooperation focuses on basic research. The most frequently used instrument is mobility support. Thus, not surprisingly, the budgets linked to bilateral agreements are mostly limited with annual amounts usually below $€ 1$ million. Most recent trends, however, show a shift from mobility towards more substantial R\&D projects, a higher share for supporting applied research and innovation and an evolution from bilateral towards multilateral schemes (Kougiou et al. 2010).

Russia is still intensively connected to its neighbouring countries in EECA at different cooperation levels. At the multinational level, the most important is the recently adopted 'Intergovernmental Programme for Innovation Cooperation of the Commonwealth of Independent States'. ${ }^{g}$ Bilateral S\&T agreements have been concluded with all EECA countries except Turkmenistan. ${ }^{\mathrm{h}} \mathrm{R} \& \mathrm{D}$ cooperation within the Commonwealth of Independent States (CIS) is facilitated by the fact that Russian is considered as lingua franca among the scientific communities. In addition to the strong traditions and ties within the CIS, R\&D cooperation with other Asian countries rapidly increases. The Russian Fund for Basic Research for instance regularly runs joint calls with the Japanese Society for the Promotion of Science, the State Fund for Natural Sciences of China and with the Indian Department of Science (Spiesberger 2008).

Russian scientists participate also in projects launched under the European initiatives COST and EUREKA. Among all non-COST member countries, Russia has the highest participation in COST actions. Russian participation in EUREKA, however, is comparatively low, which confirms the limited innovation capacities of the country.

The latest joint EU-Russia initiative is a 'partnership for modernization', agreed in spring 2010. It includes cooperation in R\&D and innovation. Regarding the latter, certain emphasis is on aligning technical regulations and standards between the EU and Russia and on enforcing IPR.

\section{International S\&T cooperation in Eastern European countries (without Russia)}

The official S\&T policy of all Eastern European neighbourhood countries acknowledges the importance of strengthening international R\&D cooperation. Provisions (articles, paragraphs etc.) are included in the respective national legislations (e.g. Armenia: Law on Scientific and Technological Activity, the Strategy on Development of Science and Action Plan 2011-2015; Georgia: Law on Science and Technologies and their Development; Moldova: Code On Science and Innovation; Moldova Knowledge Excellence Initiative
Action Plan 2008; Ukraine: National Indicative Programme 2011-2013). International S\&T cooperation, for example, has got a special line in the Belarusian $R \& D$ state budget reserving $3 \%$ to $4 \%$ for international $R \& D$ activities annually. However, there is no distinct policy document referring to the issue of international $R \& D$ cooperation in any country.

Some of the national $R \& D$ programmes are open to foreign researchers, but usually, funds are provided only to domestic researchers.

The Eastern European countries signed bilateral agreements mainly with other CIS countries and countries of the EU. Some countries have also signed agreements with nonEU countries such as USA (Armenia), Argentina (Armenia), China (Armenia, Belarus, Moldova), India (Armenia, Belarus) and Venezuela (Belarus). Moreover, bilateral agreements have also been signed by research institutions (mainly the National Academies of Sciences) with similar counterparts abroad.

In addition to the national programmes, there are also a number of bilateral programmes in force involving other national bodies as well research organisations and centres. Examples are the following:

- Collaborative Programme between CNRS, France and the State Committee of Science of the Republic of Armenia

- The Science and Technology Entrepreneurship Programme between CRDF, USA and Georgian organisations

- The collaborative calls between the Academy of Sciences of Moldova (ASM) and the Russian Foundation for the Humanities, as well as between the ASM and the German Federal Ministry of Education and Research

- Several joint programmes of Belarus and Russia, e.g. the family of programmes for developing supercomputers - 'SKIF' (2000 to 2004), 'TRIADA' (2005 to 2008) and 'SKIF-GRID' (2007 to 2010) with its follow-up, 'ORBISS' (2012 to 2015)

The regional cooperation within the EECA region is based on numerous bilateral inter-governmental agreements as well as on agreements between specific research institutions (academies, universities, research centres). The collaboration with Russia is characterized by the highest indices (e.g. in Belarus, 55\% of the Academy's international projects are carried out with Russia). Overall, regional cooperation is mainly driven by personal or institutional links often inherited from Soviet times. In addition, regional cooperation also benefits from cross border programmes under the European Neighbourhood Policy Instrument (ENPI) (especially the Black Sea Cross Border Cooperation Programme 2007-2013 and the Black 
Sea Basin Joint Operational Programme 2007-2013). Also, important for fostering the regional cooperation in S\&T is the participation of almost all Eastern European countries in regional organisations such as the Black Sea Economic Cooperation and/or the Organization for Democracy and Economic Development (GUAM) which provide forums for political dialogue in various sectors including S\&T. Within ENPI, however, S\&T is not seen as a priority area for funding as such but can be supported only for regulatory reform and capacity-building activities (as it is the case with the operation of the Joint Support Office of the EC Nuclear Safety Programme for Ukraine).

According to the EU's Competitiveness and Innovation Framework Programme (CIP) regulations, this programme is open to third countries too. From the Eastern European neighbourhood countries, Armenia, Moldova and Ukraine participate in the Enterprise Europe Network of CIP ${ }^{\mathrm{i}}$ (a network of regional consortia providing integrated business and innovation support services for small and mediumsized enterprises (SMEs)) without receiving financial support from the programme. In addition, Moldova and Ukraine participate in the Intelligent Energy Agencies initiative of CIP again without financial support from the programme. All other Eastern European neighbourhood countries have not been involved yet in CIP.

\section{International S\&T cooperation in the Central Asian countries}

International cooperation plays an increasingly acknowledged role in the implementation of the national S\&T strategies in all Central Asian countries. International relations are usually regulated through presidential decrees (Uzbekistan, Tajikistan) or through the current laws on science (Kirgizstan, Kazakhstan, Tajikistan, and the law 'On the Status of Scientists' in Turkmenistan). The main national objectives of the Central Asian countries regarding international S\&T cooperation include the following aspects: (a) exchange of S\&T knowledge, (b) financial and technical support and (c) creation of joint research centres and organisations. The Kazakh State Programme 'The Path to Europe 2009-2011' is the only explicit international strategy established at national level. The aim of this programme is to bring the Republic of Kazakhstan to an advanced level of strategic partnership with leading European countries, especially in technological important fields like energy and transport, cooperation with SMEs as well as in social sciences and humanities.

The number of national programmes in Central Asia open to foreign researchers is significantly low. In Kazakhstan, the new 'Law on Science' encourages the participation of foreign researchers in national calls for proposals. Turkmenistan allows foreign participation in national programmes as part of technical assistance, but currently, the foreign participation in scientific activities includes mainly scientists from EECA, but not from other European countries.

Each Central Asian country has signed a few bilateral S\&T agreements with different EU member states, for example, the Agreement between the Government of Kazakhstan and the Government of Italy on Cultural and Scientific Cooperation (11 May 2000), or the agreements between the government of Kazakhstan and the governments of Latvia and Estonia on economic and scientifictechnical cooperation (March 2006). Aside from the EU, the countries have built up formal scientific relations with China (Kyrgyzstan), South Korea (Uzbekistan), USA (Uzbekistan, Tajikistan) or Afghanistan, Iran, Pakistan and India (Tajikistan). They traditionally cooperate very closely with the other countries of the former Soviet Union like Armenia, Belarus, Russia, etc. Besides government level agreements, bilateral collaboration is established also at the level of research-performing organisations, such as the national academies of science, state research centres and universities.

A considerable number of S\&T cooperation agreements have been signed with the neighbouring countries in the years immediately after independence. Russia still remains the main S\&T partner of the Central Asian countries. However, among others, the political situation in the region (e.g. conflicts in Tajikistan, Kyrgyzstan) influences strongly the scientific cooperation. Overall, the regional cooperation is still driven by the past (meaning Soviet) personal or institutional links, although also new initiatives emerged in the last few years. A good example for an existing regional approach is the University of Central Asia which operates in three countries of the region, i.e., Kazakhstan, Kyrgyzstan and Tajikistan. Further examples are as follows:

- The Eco-Regional Programme for Sustainable Agricultural Development in Central Asia and the Caucasus, ' a consortium of eight national agricultural research centres, eight centres of the Consultative Group for International Agricultural Research (CGIAR) and three additional advanced research institutions (non-CGIAR consortium members)

- The International Fund for Saving the Aral Sea with the five Central Asian countries as member states, coordinating cooperation at national and international levels in order to use existing water resources more efficiently and to improve the environmental and socioeconomic situation in the Aral Sea Basin

- Or the Central Asia and Caucasus Association of Agricultural Research Institutions, ${ }^{\mathrm{k}}$ which aims at facilitating regional cooperation in agricultural research by providing a dialogue platform to the various stakeholders of the agricultural arena and by 
supporting information flow from globally operating organisations to local partners and back

In the 1990s, the European Union launched Partnership and Cooperation Agreements with the Central Asian countries which also provide an umbrella for cooperation in S\&T. Since the adoption of 'The EU and Central Asia: Strategy for a New Partnership' by the European Council in June 2007, the EU has intensified its relationship with the whole region. The strategy is supported by a significant increase of the EU's technical assistance in the region supporting higher education cooperation and academic and student exchanges under the new Erasmus Mundus facility and TEMPUS.

The Development Cooperation Instrument (DCI) (2007 to 2013) is a European programme for poverty reduction, sustainable economic and social development and the integration of Central Asia into the world economy. It is endowed with a total budget of $€ 719$ million. In general, DCI projects are not targeting dedicated R\&D topics, but some of the projects include scientific knowledge generation activities and are therefore - at least to some extent - related to scientific research. Out of 176 supported projects, 29 contain educational and scientific issues. Nevertheless, there seems to be a lot of room for advancing the link between scientific research and problem-solving approaches for poverty reduction and social and economic development.

Summing up the EU perspective towards R\&D cooperation with EECA countries, the CREST working group on R\&D internationalisation revealed that almost all European countries rank USA, China and Japan as the most important target countries for cooperation within their own R\&D internationalisation policy focus. Russia and India were among the next group of target countries, but mentioned by a significantly lower number of EU member states. With the exception of Ukraine, all other EECA countries were not among the prioritised cooperation target countries (Sonnenburg et al. 2008). On the other hand, some Eastern European countries are in the immediate neighbourhood to the EU bordering Norway, Finland, Estonia, Latvia, Lithuania, Poland, Slovak Republic, Hungary, Romania and via the Black Sea also Bulgaria. Moreover, as described above, cooperation with the European neighbourhood countries, also in the field of S\&T, is an explicit priority of the EU's foreign policy.

\section{Current state of S\&T in the Eastern European and Central Asian countries}

The R\&D capacities of the EECA region, are characterised by a general low level of R\&D expenditures (except for Russia) which generate only limited scientific and economic results. Funding for R\&D in the five Central Asian countries is generally low and ranges from $0.06 \%$ of gross domestic product (GDP) (Tajikistan) to $0.21 \%$ (Kyrgyzstan) in 2011 (see Table 1). Also, in most Eastern European countries, R\&D Gross expenditure by GDP is very low. Yet, three groups can be differentiated: The highest values are observed in Belarus and Ukraine, with an R\&D expenditure rate of $0.65 \%$ and $082 \%$, respectively (Table 1 ). The second group - comprising Georgia and Moldova - spends around $0.4 \%$ of their GDP on R\&D. Lowest R\&D expenditure was reported for Armenia and Azerbaijan with less than 0.3\%, which is similar to R\&D spending in the Central Asian countries. However, positive trends can be observed too. In some cases, the change might seem undetectable, e.g. in Belarus where the expenditure share remained almost unchanged in the period from 2001 to 2009, but since the country's GDP rose very rapidly, the amount of funding in nominal terms has also increased. In some cases, the goals to improve the situation are ambitious; such is the case in Azerbaijan where a recently announced strategy for S\&T foresees a tremendous increase from $0.2 \%$ to $2 \%$ by 2015 . However, it is also true that in some cases, the spending dropped drastically as a result of the recent financial crisis.

In the EECA region, Russia presents the highest R\&D quota (1.24\% in 2009), although it grew even further in 2010. Russian R\&D allocation in 2008, expressed in purchasing power parity, corresponded roughly to the R\&D allocations of Canada, India or Italy (HSE 2010). In Russia, like in the other EECA countries, R\&D is largely funded from the state budget, and the scarce resources are mainly concentrated in the public-influenced sector, usually characterised by low research commercialisation results.

Typically, state-funded R\&D is allocated through core funding and/or through competitive mechanisms such as programme type schemes and competitive grants. In certain countries, however, (e.g. in Belarus) the predominant method for financing research has the characteristics of public procurement, with the project proposals selected on a competitive basis, either for basic or applied research, and the results owned by the state or state-owned organisations.

Like other EECA countries Russia also faced a significant decrease of the number of researchers. ${ }^{1} \mathrm{R} \& \mathrm{D}$ personnel in the Russian Federation counted 742,433 heads in 2009, which is $2 / 3$ of the 1991 value. In full-time equivalents, Russia has five times more R\&D personnel employed than Brazil, Canada or Italy and little less than Japan. The percentage of R\&D personnel by 10,000 employees brings Russia at equal level to Germany and above Korea or the United Kingdom. However, only half of the R\&D personnel in Russia are researchers, and therefore, in reality, Russia clearly falls behind Korea and UK. Since 1991, the highest drop in absolute numbers of researchers occurred in the business-enterprise sector, which was the largest employer for researchers in the country. 
Table 1 Main S\&T indicators of the EECA countries

\begin{tabular}{|c|c|c|c|c|}
\hline EECA countries & & $\begin{array}{l}\text { R\&D expenditure as \% of GDP } \\
\text { (GERD) }\end{array}$ & Number of research organizations & Number of R\&D personnel \\
\hline \multirow[t]{5}{*}{ Central Asian countries } & Kazakhstan $^{\text {a }}$ & 0.16 & 424 & 17,021 \\
\hline & Kyrgyzstan ${ }^{\mathrm{b}}$ & 0.21 & 84 & 5,125 \\
\hline & Tajikistan ${ }^{c}$ & 0.06 & 67 & 5,617 \\
\hline & Turkmenistan & $\mathrm{n} / \mathrm{a}$ & $46^{h}$ & $3,689^{j}$ \\
\hline & Uzbekistan $^{d}$ & 0.20 & 202 & 34,587 \\
\hline \multirow[t]{7}{*}{ Eastern European countries } & Armenia & 0.27 & 83 & $6,926^{k}$ \\
\hline & Azerbaijan & 0.2 & 146 & 22,500 \\
\hline & Belarus & $0.65^{f}$ & 446 & 20,571 \\
\hline & Georgia $^{e}$ & 0.4 & 31 & 3,200 \\
\hline & Moldova & 0.42 & 38 & $4,764^{\prime}$ \\
\hline & Russia & 1.24 & 3,536 & $742,433^{m}$ \\
\hline & Ukraine & $0.82^{9}$ & $1,303^{i}$ & $141,000^{n}$ \\
\hline
\end{tabular}

${ }^{a}$ According to the Kazakhstan Agency for Statistics. www.stat.kz; ${ }^{b}$ National Statistic Committee of the Kyrgyz Republic, 2010; ${ }^{c}$ UNESCO Science Report 2010;

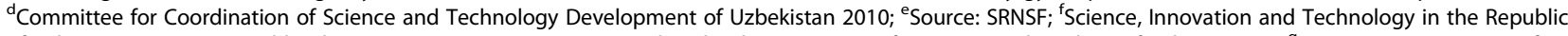
of Belarus - 2008. Statistical book, State Committee on Science and Technology, Ministry of Statistics and Analysis of Belarus, 2009; ${ }^{9}$ State Statistics Service of Ukraine: Science and Technology Activities in Ukraine - Statistical Data Collection (Державна Служба Статистики України: Наукова та інноваційна діяльність в Україні - Статистичний збірник, ДП 'Інформаційно-видавничий центр Держстату України') Kiev, 2011, p. 178 (data for 2010); 'Estimated; 'State Statistics Service of Ukraine: Science and Technology Activities in Ukraine - Statistical Data Collection (Державна Служба Статистики України: Наукова та інноваційна діяльність в Україні - Статистичний збірник, ДП 'Інформаційно-видавничий центр Держстату України') Kiev, 2011, p. 10 (data for 2010); 'Statistical Yearbook of Turkmenistan, Ashgabat, 2010, p.160; ${ }^{\mathrm{N}}$ National Statistical Service of RA, http://armstat.am/ (data for 2009); 'The Court of Accounts of Moldova Report, http://lex. justice.md/viewdoc.php?action=view\&view=doc\&id=338497\&lang=1; ${ }^{\mathrm{m}}$ Number of researchers is 369, 237 (2009); ${ }^{\mathrm{n}}$ State Statistics Service of Ukraine: Science and Technology Activities in Ukraine - Statistical Data Collection (Державна Служба Статистики Украӥни: Наукова та інноваційна діяльність в Україні - Статистичний збірник, ДП 'Інформаційно-видавничий центр Держстату України') Kiev, 2011, p. 31 (data for 2010); number of researchers is 89,600.

Ageing of R\&D personnel remains a problem in most Eastern European countries. Since a considerable part of the most active mid-age and young scientists have moved abroad or left the research sector, the research teams are currently composed to a large extent by researchers close to the retirement age. In Russia, more than $50 \%$ of researchers are above 50 years of age. Low wages and weak career prospects for young researchers are a common issue, resulting in a continuous brain drain problem. However, attempts are made to attract young scientists, usually through involvement in international programmes and/or through incentives to the diaspora (e.g. in Armenia and Moldova, and recently initiated in Georgia).

Regarding the number of research organisations in absolute figures, Russia and Ukraine have, by far, the highest numbers followed by Belarus, Kazakhstan, Uzbekistan and Azerbaijan (see Table 1). All the other EECA countries count less than 100 research organisations. In most EECA countries, the national Academy of Science is central to the research system of the country. In some countries, like in Moldova, Tajikistan or Kyrgyzstan, it even defines and coordinates the research activities across all public institutions, including public universities, and manages state funds for basic research (the latter also in Ukraine and to a certain extent, also in Russia). In Turkmenistan, the vice prime minister for science, new technologies and innovation is also the president of the Academy of Science.
The president of the Moldovan Academy of Science has a similar influential position. In almost all EECA countries, the academies in the future are supposed to be more engaged in applied research and in the cooperation with universities and the economic sector. For instance, in 2011, Armenia adopted a new 'Law on the National Academy of Sciences of Armenia' which stipulates wider possibilities for the Academy to carry out business activities and to commercialise $R \& D$ results.

With few exceptions, like in Georgia where the research institutes have been integrated in the university system, the universities until recently have occupied a rather modest place in the EECA research systems. Only approximately $40 \%$ of the 1,114 higher education institutes in Russia (data for 2009) are actually involved in R\&D, and only approximately $20 \%$ of all professors and teachers conduct research (I Dezhina and M Spiesberger, unpublished work). Nonetheless, the situation is changing. Funding from the academies is increasingly redirected to universities through a number of new initiatives, such as the awarding of a special status of 'Federal University' or 'National Research University'. These statuses are accompanied by generous federal budget funding. Ukraine also attempts to boost the integration of research in universities ('Programme for Science in Universities 2008-2012'). Moreover, in Ukraine, Belarus, Georgia and Armenia, the reform of the higher education system along the lines of the Bologna process is a priority. 
Although almost all EECA countries aimed to reform their S\&T systems in a way to respond to new economic and social requirements by introducing previously nonexistent mechanisms (e.g. introduction of competitive funding schemes; enhancing linkages with universities and teaching), their national systems of innovation still have striking weaknesses in interlinking with economic and societal demands as well as with different fields of policy. Despite the intention of the political elite to consider innovation-oriented R\&D agendas a priority and to support a diversification of the economy beyond primary goods production, $R \& D$ performance in the businessenterprise sector is still weak. Even in Russia, the number of small innovative enterprises is remarkably limited and estimated at 25,000. It should be noted, however, that some statistical appropriation problems hinder an exact assessment. In general, it can be concluded that SMEs are still not in a position to act as engines of innovation and that large enterprises account for the majority of innovation activities.

\section{The White Paper recommendations in the light of international S\&T cooperation policy objectives}

A group of organisations from nine EU member states, two countries associated to FP7 and nine EECA countries (including Moldova which became associated to FP7 on 1 January 2012), all of them with a public or semi-public mandate, working together under a joint international S\&T policy coordination project (INCO-NET EECA), funded by the European Commission, prepared the 'White Paper on Opportunities and Challenges in View of Enhancing the EU Cooperation with Eastern Europe, Central Asia and South Caucasus in Science, Research and Innovation'. The White Paper is based on the conclusions of three policy stakeholder conferences organised under the INCO-NET EECA project (Athens/2009, Moscow/2010, Astana/2011), on fact-finding missions to all EECA countries, on a series of expert workshops on several relevant topics (e.g. S\&T statistics) and on a public consolidation via the internet. Furthermore, the White Paper integrates extensive desk research and has been consolidated in a dedicated policy stakeholder conference in Warsaw (November 2011). ${ }^{\mathrm{m}}$

The White Paper suggests 39 recommendations to improve $R \& D$ cooperation between the EU and the EECA countries, which is, on one hand, an indication for comprehensive deliberations but, on the other hand, also an indication for a lack of coordinated priority setting. Although a number of recommendations extend into the autonomous competences of state authorities and research performing organisations, the authors explicitly state that the 'White Paper does not intend to interfere with autonomous decision-making processes but to contribute to the knowledge base of the international STI cooperation between EU and EECA countries with an informed input that takes into account the international perspectives of different regions and countries' (Sonnenburg et al. 2012, p. 12). In this sense, the White Paper is less of a formal policy paper than an academic piece of work reflecting and deepening an ongoing policy dialogue, which is empirically evidenced. As a first step for a more consolidated policy approach, the White Paper consequently suggests the elaboration of a medium-term joint roadmap for enhanced science, technology and innovation (STI) cooperation between the EU, its member states and the EECA countries to be built on common goals for mutual benefit and to be implemented in partnership through joint instruments. It explicitly addresses the 'European Strategic Forum for International Cooperation' (SFIC) as the highest S\&T internationalisation policy forum at the European level involving the EU member states, to launch a new SFIC pilot activity, by inviting EECA partner countries to join the dialogue and to monitor upcoming joint activities. With this suggestion for a procedural hand over, the perceived lack of policy legitimisation, caused by the facts that the White Paper is (1) a project deliverable and not an institutionalised spring-off and (2) prepared by a limited number of institutions (although by all means influential) which can neither represent the EU nor each single EECA country, should be overcome. The authors of the White Paper also call for more and broader consolidation when they write that the 'process of developing a joint roadmap needs to include wider stakeholder consultations in particular with the science community and the private sector in both regions' (Sonnenburg et al. 2012, p. 12).

The core part of the White Paper consists of the 'challenges and recommendation' section. The recommendations are disaggregated in five major topics, which are reflected in the context of S\&T internationalisation objectives as outlined in the 'Internationalisation of R\&D from an S\&T policy perspective' section of this article, as follows.

\section{Adjusting and implementing policy strategies}

In this first thematic block, several recommendations directly related to strategic policy making and good governance are subsumed, such as generating, accessing and using standardised and internationally comparable data and knowledge for evidence-based policy making; embedding science, technology and innovation (STI) policy and policy delivery in a broader and aligned strategic policy system; building appropriate and internationally compatible national legal and ethical frameworks; strengthening the institutional fabric of the STI policy delivery systems with efficient tools and instruments; securing a sufficient financial allocation to the STI sector; identifying and addressing global and societal challenges, and making optimum use of international cooperation.

From an international R\&D cooperation perspective, the focus of these recommendations is clearly on supporting 
strategic STI policy making, primarily perceived as a domestic endeavour, by implementing - as a supplement to the domestic homework - a series of international learning exercises (involving country representatives from the EU and EECA countries), improving existing international STI cooperation frameworks at national level (again based on international best practices exchange and/or international benchmarking exercises) and contributing to exchange and coordination activities at the international and global level. In this understanding, this first major block of recommendations is driven by an advanced interpretation of science diplomacy, which aims at supporting the establishment of a smooth multifaceted framework for future enhanced international R\&D cooperation. The addressed actor is clearly S\&T policy (respectively S\&T policy makers), which could make use of experts as facilitators, who are either internal or external to the S\&T policy system. While the actors targeted by these recommendations are from the sphere of policy making and policy delivery, the intended final beneficiaries of their work are, however, both private and public R\&D organisations.

\section{Strengthening research performing institutions}

The second block of recommendations aims to strengthen research-performing institutions in order to make objectives related to international S\&T cooperation attainable (e.g. tackling global challenges). In other words, research performing institutions have to be in the material and immaterial position to efficiently perform their duties (also in international division of labour), to adjust to changing demands of the society and economy and to possess capacities and capabilities needed for international S\&T competition and cooperation.

It goes without saying that such a focus, directly targeting research-performing actors, is typically a central matter of domestic S\&T policy. The White Paper complements this domestic perspective again by an international $R \& D$ cooperation perspective, suggesting to strengthen researchperforming institutions through their involvement in international benchmarking exercises and twinning activities, which contribute to the adoption of good practices; to strengthen their strategic and operational capabilities through participation in international trainings and through the application of modern management techniques; and to establish and implement roadmaps, investment plans and management concepts for an improved development and exploitation of research infrastructures. Such an R\&D internationalisation perspective falls partly under the development objective, where the improvement of local $R \& D$ capacities in developing countries recently gained attention (Bucar 2010; Schuch 2007), and partly under the cost optimisation objective when it comes down to a shared development and exploitation of research infrastructures.
Again, the actors addressed by this block of recommendations are largely stakeholders representing S\&T policy making and policy delivery. Also, directors of R\&D organisations, which are presumably public by nature, are directly targeted. It is likely that the interventionist power of public S\&T policy will hardly reach out to private R\&D organisations when strategic management issues (such as benchmarking, application of Balanced Score Cards or market foresight) are concerned. The final beneficiaries are again R\&D-performing organisations.

\section{Strengthening human resources}

The third block of recommendations identifies human capacity building as a particular challenge for all countries, especially in front of societal and economic transformation processes which require also an improved quality of communicating science to society. From the perspective of an international S\&T cooperation policy, the adjustment of frameworks for international mobility is a particular challenge, especially in front of ongoing brain drain/brain gain dynamics which also take place between EU and EECA countries, expressing an unidimensional direction to the advantage of the more central EU and to the disadvantage of the more peripheral EECA countries.

The suggested recommendations, however, do not aim to put a firm halt on this lopsided brain movement, but rather follow a more liberal and multifaceted approach. The White Paper suggests to set up joint training and twinning activities, especially targeting young researchers; to further align scientific education schemes based on Bologna principles; to establish instruments for a more balanced mobility for students and researchers, e.g. through regional doctoral programmes; to further facilitate the issuing of scientific visa; to implement an EU-EECA Year of Science and to promote modern science communication.

From an R\&D internationalisation policy perspective, the focus is on the resource acquisition objective, which in principle is true for both sides. Strategically important in this respect is the promotion and extension of European higher education standards (Bologna principles) towards the EECA region, which doubtlessly facilitates the international mobility of students and researchers, however, presumably at an uneven level-playing field which usually benefits the standard setter against the standard adopter. The actor targeted by these recommendations is primarily again S\&T policy making and policy delivery, but a few recommendations can also be directly taken up by research organisations themselves. The intended final beneficiaries are, first of all, mobile (which typically means young) researchers.

\section{Strengthening the role of the private sector}

The fourth block of recommendations addresses R\&D activities in the private sector. This is a policy issue which 
typically falls again under domestic S\&T policies. From an international $R \& D$ perspective, the White Paper suggests some flanking measures, carried out through international cooperation, to support private R\&D stimulation, e.g. through implementing joint international training courses on innovation management as well as international learning activities on stimulating the creation and nurturing of innovative companies and framework setting for a higher private engagement in science, technology and innovation; to provide linkages between industry-related R\&D initiatives in the EU and similar structures in EECA and to establish joint competitive innovation funding programmes; to improve the conditions for investments in innovation and to encourage EU-EECA cooperation in this respect.

Most of these recommendations clearly fall under the market and competition objective, although often dressed in the wording of science diplomacy. Soft measures like international learning and exchange platforms, but also a few hard measures, such as establishing (and budgeting) competitive multilateral RTDI funding programmes, are explicitly suggested. Moreover, from an international R\&D perspective, also policy issues are addressed which are increasingly dealt with at supra-national and/or global level (e.g. investment regulations at WTO level).

The addressed actor's level is that of S\&T policy makers. The intended final beneficiaries are companies which should make use of the improved framework conditions and jointly established international instruments (e.g. joint calls for proposals).

\section{Strengthening subregional cooperation}

The fifth block of recommendations focuses on the reduction of the fragmentation of the EECA region and on the increase of critical mass through subregional cooperation. In this respect, the White Paper suggests to strengthen subregional policy coordination and to stimulate networking between the science, technology and innovation communities, as well as to investigate the possibility of establishing regional centres of excellence. This block of recommendations is the least elaborated one because it refers only to the EECA region and does not emphasise international S\&T cooperation between EU and EECA countries. It is a science diplomacy issue internal to the EECA region and clearly addresses the policy level as actor.

\section{Implementation scenario}

The White Paper suggests a short-term implementation scenario summarizing some of the suggested recommendations addressed to specific groups of stakeholders which can be implemented by utilising the existing cooperation instruments. Particular attention is given to existing programmes like the EU Framework Programme for RTD, the ENPI and the DCI as well as to ongoing and planned projects implemented hereunder such as the INCO-NET,
BILAT and ERA-NET schemes. The White Paper also includes a roadmap, which suggests recommendations to be implemented at short, medium or long term, as well as a qualitative impact assessment, which estimates the expected impact of each recommendation on the national research performance, on human resources for $R \& D$, on the innovation potential, on the participation in FP7 respectively its follow-up programme 'Horizon 2020', on addressing global challenges, on employment and on growth in general.

\section{Conclusions}

By identifying the policy objectives addressed in the White Paper, it becomes obvious that the objective which is usually regarded as the major intrinsic objective for conducting international R\&D cooperation (Boekholt et al. 2009; Sonnenburg et al. 2008), namely, the 'quality acceleration and excellence objective' is hardly directly addressed by the recommendations. Several suggestions, however, clearly aim to improve the state-of-art policies and instruments as well as the performance of research (organisations). These seem to be influenced rather by the spirit of science diplomacy and development cooperation than by the spirit of $R \& D$ excellence. The reason for this might be a perceived lopsided learning direction, which in general seems to go from the EU to the EECA countries (or possibly also from Russia to other EECA countries). This tilted position is neither a priori hegemonic nor surprising because many policy makers from EECA countries expressed the need to upgrade their national innovation systems, and the EU clearly offers a level-playing dialogue field for this with the INCO-NET, ERA-NET and BILAT-projects within FP7, which are used to establish platforms for learning and exchange. Presumably, with the exception of Russia, which progressed already a lot in modernising its national system of innovation (although without being in the position to lean back because S\&T policy - like any policy field - is a moving target), most EECA countries are still undergoing basic reforms of their S\&T system or have just implemented them. Their national innovation systems also suffer from a legacy of unfinished reforms. In most countries, amendments to laws, new strategy papers and even new institutionalised missions are more frequently published than rightfully implemented. Moreover, most countries of the region under scrutiny belong to laggards in terms of $R \& D$ intensity as shown in the 'Current state of S\&T in the Eastern European and Central Asian countries' section.

Although the intended beneficiaries of the suggested recommendations featured in the White Paper are researchers and/or research organisations, both from industrial and academic background, the actor usually directly targeted by most recommendations is the S\&T policy (delivery) system. The recommendations proposed in the White Paper feature an international cooperation 
dimension, which is understood to accompany domestic policies through offering relevant international dialogue, exchange and learning platforms. Most of the suggested recommendations are soft by nature, building on mutual interest, trust, benevolent interaction and a voluntarily participation based on 'variable geometry'. Such platforms, which also employ specific tools (e.g. international benchmarking exercises, S\&T policy reviews, etc.) are considered as starting points for a subsequent improvement of the overall framework conditions for international $R \& D$ cooperation between researchers and research organisations from the EU and EECA countries. In such a step-by-step approach, also the ultimate quality acceleration and excellence objective is prepared and serviced, although other S\&T policy objectives play a more immediate role in the short run, especially science diplomacy in its enabling function.

In that respect, the White Paper constitutes a valuable reflexive tool, and it can be expected that the implementation of the suggested recommendations will be beneficial not only to the EU-EECA cooperation, but also to the strengthening of the research systems in the EECA countries. However, to commence the implementation, it is necessary to identify and prioritize a limited set of recommendations. Such prioritization process can be the result of the continuing policy dialogue but would doubtlessly benefit from support at the highest political level at a certain moment (e.g. through the adoption of an action plan at ministerial level).

\section{Endnotes}

a CREST (since 26 May 2010 renamed into ERAC: European Research Area Committee) is a strategic policy advisory body whose function is to assist the European Commission and the Council of the European Union in performing the tasks incumbent on these institutions in the sphere of research and technological development.

b Austria, Belgium, Czech Republic, Denmark, Germany, Greece, Finland, France, Ireland, Island, The Netherlands, Norway, Poland, Portugal, Romania, Slovenia, Spain, Sweden, Switzerland, Turkey and United Kingdom.

c This assumption can, however, be challenged. A deliberation on this is provided by Schuch (2011).

$\mathrm{d}$ defined as the duality of competition and cooperation expressed on competitive markets.

e http://www.inco-eeca.net/en/119.php.

${ }^{\mathrm{f}}$ See http://www.access4.eu/index.php for more information

g http://rs.gov.ru/topic/185

h Taken from http://mon.gov.ru/work/mez/dok/1075/

${ }^{\mathrm{i}}$ EEN Members:

http://www.enterprise-europe-network.ec.europa.eu/ about/branches

${ }^{j}$ http://www.icarda.org/cac/

${ }^{\mathrm{k}}$ http://www.cacaari.org/ l An exception is Belarus, where R\&D employment increased by $5 \%$ between 2003 and 2008 .

$\mathrm{m}$ Activities organised in the context of the following projects funded by the European Commission (FP7) and dedicated to the support of the EU-EECA policy dialogue have been taken into account too:

- 'S\&T International Cooperation Network for Eastern European and Central Asia - INCO-NET EECA'

- 'S\&T International Cooperation Network for Central Asia and South Caucasus - INCO-NET CA/SC'

- 'Enhancing the bilateral S\&T Partnership with the Russian Federation (BILAT-RUS)'

- 'Enhancing the bilateral S\&T Partnership with Ukraine (BILAT-UKR)'

- 'Linking Russia to the ERA: Coordination of MS/AC S\&T Programmes towards and with Russia (ERANET RUS)'

- 'Networking on Science and Technology in the Black Sea Region (BS-ERA.NET)'

\section{Competing interests}

The authors declare that they have no competing interests.

\section{Acknowledgements}

This article was prepared under the INCO-NET EECA project, funded by the European Commision. The authors acknowledge Tigran Arzumanyan, Adalat Hasanov, Olga Meerovskaya, Theodore Dolidze, Nikoloz Bakradze, Kamila and Sulushash Magzieva, Jyldyz Bakashova, Sergiu Porcescu, Diana Grozav, Anna Pikalova, Liliana Proskuryakova, Ilkolm Mirsaidov, Dovlet Jumakuliev, Vadym Yashenkov, Olena Koval, Rustam Saidov and Durdona Komilova for their contributions to the acquisition and interpretation of data.

\section{Author details}

${ }^{1}$ Centre for Social Innovation, Linke Weinzeile 246, Wien 1150, Austria. ${ }^{2}$ International Centre for Black Sea Studies and National Hellenic Research Foundation, 4 Xenophontos Street, Athens 10557, Greece.

${ }^{3}$ International Bureau of the Federal Ministry of Education and Research, Heinrich-Konen-Street 1, Bonn 53227, Germany.

Authors' contributions

All authors read and approved the final manuscript.

Received: 8 June 2012 Accepted: 8 August 2012

Published: 8 August 2012

\section{References}

Archibugi, D., \& Michie, J. (1995). The Globalisation of Technology: a new taxonomy. Cambridge Journal of Economics, 19(1), 121-140.

Boekholt, P., Cunningham, P., Edler, J., \& Flanagan, K. (2009). Drivers of international collaboration in research. Synthesis report to the EU Commission. Brussels: Technopolis and Manchester Institute of Innovation Research. April 2009.

Bucar, M. (2010). Science and technology for development. Coherence of the common EU R\&D policy with development policy objectives. Discussion paper 19/2010 of the German Development Institute. Bonn: Deutsches Institut für Entewicklungspolitik.

Cantwell, J. (1995). The Globalisation of technology: what remains of the product cycle model? Cambridge Journal of Economics, 19, 155-174.

Dalton, D. H., \& Serapio, M. G. (1999). Globalizing industrial research and development. Washington, D.C: U.S. Department of Commerce, Technology Administration, Office of Technology Policy.

Edler, J. (2007). Internationalisierung der deutschen Forschungs- und Wissenschaftslandschaft (Internationalisation of the German research and science landscape). Stuttgart: Fraunhofer IRB Verlag. 
Edler, J. (2008). Creative internationalization: widening the perspectives on analysis and policy regarding beneficial international R\&D activities. The Journal of Technology Transfer, 2008(4), 337-352.

Edler, J., \& Boeckholt, P. (2001). National public policies to exploit international science and industrial research. A synopsis of current developments. Science and Public Policy, 28(4), 313-322.

Edler, J., \& Flanagan, K. (2009). Drivers of policies for STI collaboration and related indicators. Manchester/Brussels: Literature Review. April 2009.

Edler, J., Meyer-Krahmer, F., \& Reger, G. (2002). Changes in the strategic mangement of technology - results of a global benchmarking study. R\&D Management, 32(2), 149-164.

European Commission. (1999). Wrap-up INCO 1 (Final): statistical overview on international RTD cooperation in FP4 (1995-1998). Brussels: European Commission. July 1999.

European Commission (2000): EU co-operation with the NIS in science and technology. Luxembourg: Office for Official Publications of the European Communities.

European Commission. (2007). The European research area: new perspectives. Green paper presented by the Commission (SEC(2007)412, COM (207) 161 final. Brussels: European Commission.

European Commission (2008): A strategic European framework for international science and technology cooperation. European Commission: Communication from the Commission to the Council and the European Parliament. Brussels.

Godin, B. (2001). What's so difficult about international statistics? UNESCO and the measurment of scientific and technological acitivities. In Working Paper No. 13 of the Project on the History and Sociology of S\&T Statistics. Montreal: Canadian Science and Innovation Indicators Consortium (CSIIC).

Gokhberg, L., Gorodnikova, N., \& Wudtke, J. (1999). Volkswirtschaft im Übergang. Ein Vergleich der F\&E-Indikatoren in Russland und Deutschland (National Economy $n$ Transition. A comparison of R\&D indicators in Russia and Germany). Materialien zur Wissenschaftsstatistik, Heft 11, April 1999. Essen:

Wissenschaftsstatistik GmbH im Stifterverband für die Deutsche Wissenschaft.

HSE. (2010). Science and technology. Innovation. Information society. Pocket Data Book. Moscow: National Research University - Higher School of Economics.

Idenburg, P., Stalnacke, P., Schuch, K., Nyiri, L., Ventskonvsky, O., Mandrillon, M.-H., Sokolov, A., Eikenberg, H., \& Sorensen, O. J. (2004). External evaluation report on the programme of the International Association for the Promotion of Cooperation with Scientists from the New Independent States of the Former Soviet Union (INTAS) covering the period 1993-2003. Brussels: INTAS.

INTAS. (1995). Revised statutes adopted on 14 November 1995 in Brussels: INTAS Secretariat. Brussels: INTAS.

Kougiou, S., Spiesberger, M., \& Kerasioti, V. (2010). State of the art and perspectives of bilateral S\&T programmes between EU MS/AC and Russia and of activities of S\&T Programme Owners in EU MS/AC towards Russia and in Russia towards EU MS/AC accompanying / complementing bilateral S\&T agreements.: . Deliverable 1.3 of the ERA-NET RUS project. http://www.eranet-rus.eu/en/107.php. Accessed 12 April 2012.

Le Gohebel, M., Pecarz, D., Handler, K., \& Schuch, K. (2011). S\&T cooperation between the EU and Ukraine: benefits and barriers. Foresight, 5(3), 44-57.

Narula, R., \& Zanfei, A. (2004). Globalization of innovation: the role of multinational enterprises. In J. Fagerberg, D. C. Mowery, \& R. R. Nelson (Eds.), The Oxford Handbook of Innovation (pp. 318-345). Oxford: University Press.

OECD. (2005). Forum on the internationalisation of R\&D. background paper: internationalisation of R\&D - trends, issues and implication for S\&T policies. Paris: OECD.

OECD. (2008). Internationalisation of business R\&D: evidence, impact and implications. Paris: OECD.

Rama, R. (2008). Foreign investment innovation: a review of selected policies. The Journal of Technology Transfer, 2008(4), 353-363.

Sachwald, F. (2008). Location choices within global innovation networks: the case of Europe. The Journal of Technology Transfer, 2008(4), 364-378.

Schuch, K. (2005). The integration of Central Europe into the European system of research. Guthmann-Peterson: Wien und Mülheim a.d. Ruhr.

Schuch, K. (2007). Towards the introduction of the system of innovation concept in official development assistance. In J. Nechifor \& S. Radosevic (Eds.), Proceedings of the International Conference and High Level Round Table "Why invest in science in South Eastern Europe" (pp. 147-162). Venice: UNESCO BRESCE.

Schuch, K. (2011). Indikatoren zur Messung der Internationalisierung von Wissenschaft und Forschung (Indicators to measure internationalisation of science and research). Wien: Final Report prepared for the Austrian Ministry of Science and Research.
Sonnenburg, J., Bonas, G., \& Schuch, K. (2012). White paper on opportunities and challenges in view of enhancing the EU cooperation with Eastern Europe, Central Asia and South Caucasus in science, research and innovation. Athens: ICBSS.

Sonnenburg, J., Nill, J., Schuch, K., Schwaag-Serger, S., Teirlinck, P., \& Van der Zwan, A. (2008). Policy approaches towards S\&T cooperation with third countries. Brussels: Analytical Report on behalf of the CREST Working Group on R\&D Internationalisation.

Spiesberger, M. (2008). Country Report Russia. An analysis of EU-Russian cooperation in S\&T. Brussels: Prepared on behalf of the CREST OMC Working Group.

Verbeek, A., \& Shapira, P. (2009). Analysis of R\&D international funding flows and their impact on the research system in selected member states. Brussels: RINDICATE report by IDEA Consult, NIFUSTEP and University of Manchester on behalf of the European Commission. December 2009.

doi:10.1186/2192-5372-1-3

Cite this article as: Schuch et al:: Enhancing science and technology cooperation between the EU and Eastern Europe as well as Central Asia: a critical reflection on the White Paper from a S\&T policy perspective. Journal of Innovation and Entrepreneurship 2012 1:3.

\section{Submit your manuscript to a SpringerOpen ${ }^{\odot}$ journal and benefit from:}

- Convenient online submission

- Rigorous peer review

- Immediate publication on acceptance

- Open access: articles freely available online

- High visibility within the field

- Retaining the copyright to your article

Submit your next manuscript at $>$ springeropen.com 